\title{
Pengaruh Ekstrak Air Selada Laut (Ulva Lactuca) Terhadap Berat Badan Pada Tikus Diabetes
}

\section{The Effect of Sea Lettuce (Ulva lactuca) Water Extract to the Body Weight of DM Rats}

\author{
Rinawati ${ }^{1}$, Lili Eky Nursia $\mathbf{N}^{2}$, Sri Wahyuni Muhsin ${ }^{3}$, Siti Maisyaroh Fitri Siregar ${ }^{4}$ \\ ${ }^{1,2,3,4}$ Prodi Kesehatan Masyarakat, Fakultas Kesehatan Masyarakat, Universitas Teuku Umar Aceh Barat, \\ Indonesia \\ Email: $\underline{\text { rinawati@utu.ac.id }}{ }^{1}, \underline{\text { lilieky@utu.ac.id }}^{2}, \underline{\text { sriayu.as@gmail.com }}^{3}$, $\underline{\text { imaysya@gmail.com }}^{4}$
}

\begin{abstract}
Abstrak
Pola hidup tidak sehat merupakan salah satu penyebab munculnya penyakit Diabetes Mellitus (DM) yang ditandai oleh tingginya kadar glukosa darah melebihi batas normal. Selada laut (Ulva lactuca) merupakan salah satu jenis bahan alam yang berpotensi sebagai anti DM namun belum dikenal oleh masyarakat luas terutama di Aceh. Tujuan penelitian ini untuk mengetahui pengaruh pemberian ekstak air Ulva lactuca terhadap berat badan tikus DM. Penelitian bersifat eksperimen Rancangan Acak Lengkap (RAL). Tikus dikelompokkan menjadi 5 pelakuan dengan tiga kali ulangan,yaitu: $\mathrm{KN}=$ Kontrol normal (hanya diberi pakan dan akuades), $\mathrm{Ka}=$ Kontrol STZ (Tikus diinduksi STZ 65 mg), P1= Tikus DM + dosis ektrak 200 mg/KgBB, P2= Tikus DM + dosis ekstrak 300 mg/KgBB, P3= Tikus DM + dosis ekstrak 400 mg/KgBB. Pengukuran Berat Badan (BB) tikus dilakukan selama 28 hari. Analisis data dilakukan secara statistik (ANOVA). Hasil penelitian menunjukkan bahwa ekstrak air Ulva lactuca berpengaruh terhadap perubahan berat badan tikus DM. Kelompok perlakuan P1, P2 dan P3 mengalami kenaikan berat badan setelah diberi ekstrak air Ulva lactuca. Persentase kenaikan tertinggi terdapat pada kelompok perlakuan P2 dan P3.
\end{abstract}

Kata Kunci: Diabetes Millitus, Berat, Selada laut (Ulva lactuca)

\section{Abstrack}

Unhealthy lifestyle is one of the leading causes to Diabetes Mellitus (DM) disorder which is characterized by beyond normal limits of high blood glucose levels. Seawed (Ulva lactuca) is one type of natural material that is potentially to be anti-DM. Unfortunately, it is not familiar yet to the wider community, especially in Aceh. The purpose of this study was to determine the effect of giving Ulva lactuca water extract to the body weight of DM rats. The research is an experimental completely randomized design (CRD). Rats were grouped into 5 treatments with three replications, namely: $K N=$ normal control (only fed and distilled water), Ka $=S T Z$ control (rat induced STZ $65 \mathrm{mg}$ ), P1 = rat DM + extract dose $200 \mathrm{mg} / \mathrm{KgBB}, \mathrm{P2}=\mathrm{DM}$ rats + extract dose 300 $\mathrm{mg} / \mathrm{KgBB}, \mathrm{P3}=\mathrm{DM}$ rats + extract dose $400 \mathrm{mg} / \mathrm{KgBB}$. Measurement of body weight (BB) of rats was carried out for 28 days. Data analysis was performed statistically (ANOVA). The results showed that the water extract of Ulva lactuca affected the changes in body weight of DM rats. The treatment groups of P1, P2 and P3 gained weight after being given Ulva lactuca water extract. The highest percentage of weight increase was found in the $P 2$ and $P 3$ treatment groups.

Keywords: Diabetes Mellitus, Weight, Sea Lettuce (Ulva lactuca)

PENDAHULUAN

Pola hidup tidak sehat merupakan salah satu pemicu Diabetes Mellitus (DM). Menurut Zang (2020) orang yang menerapkan pola hidup sehat, $75 \%$ lebih rendah akan mengalami DM dibandingkan dengan yang menjalankan pola hidup tidak sehat. Meskipun DM dapat berasal dari genetik, namun pola hidup tidak sehat yang lebih banyak meningkatkan angka kasus DM World Health Organization (WHO) menyatakan DM sebagai penyebab utama kematian ketujuh pada tahun 2016. Data yang dihimpun oleh Riset Kesehatan Daerah, terjadi peningkatan dua kali lipat kasus DM tahun 2013 dibandingkan tahun 2017. Prevalensi DM tahun 2018 di Indonesia berdasarkan diagnosis tertinggi di dKI Jakarta dan terendah di NTT. Aceh termasuk provinsi yang memiliki kasus DM, Dinas Kesehatan Aceh mencatat diabetes di urutan ke dua tertinggi setelah hipertensi dengan angka 97.033 kasus.

Peningkatan kadar glukosa darah terjadi sesaat setelah makan, sedangkan jika tidak ada asupan makanan maka kadarnya 
akan menurun (Rachmawani, 2017). Kadar glukosa normal pada tubuh manusia yang sehat tidak lebih dari $140 \mathrm{mg} / \mathrm{dL}$. Berbeda dengan penderita DM, terdapat kelainan proses metabolisme karena glukosa yang seharusnya dipecah dan diolah menjadi energi tidak berlangsung sebagaimana mestinya. Hal ini diakibatkan minimnya jumlah insulin atau berkurangnya sensitifitas membran yang berperan sebagai reseptor atau kunci masuknya glukosa ke dalam sel tubuh (Dawn, 2000)

Ciri-ciri pengidap DM diantaranya adalah sering haus, sering kencing, berat badan turun secara signifikan walaupun makan dengan porsi banyak akibat sering merasa lapar. Umumnya berat badan (BB) penderita DM akan semakin menurun tidak terkontrol dan kehilangan banyak kalori karena terbuang melalui urine (Marewa, 2015). Penderita DM seringkali mengalami penurunan berat badan mendadak yang sangat signifikan diakibatkan tubuh tidak memiliki jumlah insulin yang cukup sehingga glukosa sebagai sumber energi sangat rendah di dalam tubuh. karena Glukosa yang terdapat hanya dalam jumlah kecil, maka tubuh mengambil energi yang berasal dari lemak dan otot. kejadian inilah yang menyebabkan tubuh penderita semakin kurus (Parenting, 2019). Rias (2017) melakukan penelitian menggunakan tikus sebagai hewan coba diabetes untuk mengetahui hubungan diabetes dengan berat badan. Rias menyebutkan dari hasil penelitian tersebut adalah ada kaitan erat antara diabetes dengan berat badan. Penanganan dan kontrol kadar glukosa darah sangat penting bagi penderita DM dilakukan karena penyakit ini berbahaya dan mengakibatkan berbagai komplikasi serius bagi organ tubuh yang lain (Kemenkes RI, 2014). Obat DM berbahan kimia sintetik banyak digunakan sebagai langkah pengobatan selain suntik insulin, namun ada efek samping negatif jangka panjang dari penggunaan obat-obatan (Putra, 2017). Penderita ada yang beralih pada obat herbal untuk meminimalkan efek samping (Hamzah, 2019)
Indonesia kaya dengan jenis tumbuhan yang berpotensi sebagai obat DM, namun masih banyak yang belum dimanfaatkan. Selada laut (Ulva lactuca) merupakan salah satu kekayaan alam Indonesia, biasanya dimanfaatkan sebagai bahan makanan (Arbi, 2014) sebagai anti fungi (Zulfadhli, 2018) produk Nori (Zakaria, 2017) anti hiperkolestrol (Faiuz, 2014). Sejauh penelusuran penulis, belum ada yang melakukan penelitian mengenai ekstrak air selada laut di Indonesia khususnya Aceh, sebagai antidiabetes maupun pengaruhnya terhadap berat badan.

\section{MATERIAL DAN METODE}

Alat yang digunakan pada penelitian diantaranya: Sonde, Jarum suntik (syringe), kandang tikus, wadah pakan, sarung tangan, glukometer test merk Easy Touch. Bahan yang digunakan meliputi STZ, Aquadest, tikus dan Ulva lactuca yang diambil dai perairan Aceh

\section{Rancangan Penelitian}

Penelitian ini bersifat eksperimental menggunakan Rancangan Acak Lengkap (RAL) yang dilakukan pada Laboratorium MIPA Universitas Syiah Kuala Banda Aceh. Hewan uji yang digunakan adalah tikus putih yang dikelompokkan menjadi 5 perlakuan dengan tiga kali ulangan. $\mathrm{KN}=$ Kontrol normal (hanya diberi pakan dan akuades), $\mathrm{Ka}=$ Kontrol Streptozotocin (Tikus diinduksi STZ $65 \mathrm{mg}$ ), P1= Tikus $\mathrm{DM}+$ dosis ektrak $200 \mathrm{mg} / \mathrm{KgBB}, \mathrm{P} 2=$ Tikus $\mathrm{DM}+$ dosis ekstrak $300 \mathrm{mg} / \mathrm{KgBB}$, $\mathrm{P} 3=$ Tikus $\mathrm{DM}+$ dosis ekstrak 400 $\mathrm{mg} / \mathrm{KgBB}$.

\section{Tahapan Penelitian}

\section{a. Penyiapan ekstrak selada laut}

Selada laut (Ulva lactuca) dipilah dan diambil yang utuh selanjutnya dibersihkan dari kotoran yang menempel. Helaian daun Ulva lactuca dicuci bersih dan tiriskan lalu dikeringanginkan selama lebih kurang 2 minggu hingga rapuh saat diremas. Langkah selanjutnya adalah pembuatan serbuk dilakukan penghancuran 
daun menggunakan blender lalu diayak sampai didapatkan serbuk dengan ukuran tidak terlalu halus atau terlalu kasar

\section{b. Penyiapan Hewan Uji}

Penyiapan hewan uji: tikus terlebih dahulu diinjeksi dengan larutan nikotinamid (NA) dengan dosis 230 $\mathrm{mg} / \mathrm{kgBB}$ secara peritonial, 15 menit kemudian tikus diinjeksikan streptozotocin (STZ) menggunakan dosis $65 \mathrm{mg} / \mathrm{kgBB}$. Pengukuran kadar glukosa darah menggunakan glukometer test.

\section{c. Pengujian ekstrak secara In vivo pada hewan uji}

Tabel 1. Hasil Pengukuran Berat Badan (BB) Tikus
Ekstrak air Ulva lactuca diberikan pada hewan uji secara invivo menggunakan jarum sonde dengan dosis $200 \mathrm{mg} / \mathrm{KgBB}$, $300 \mathrm{mg} / \mathrm{KgBB}$ dan $400 \mathrm{mg} / \mathrm{KgBB}$ selama 30 hari dan setiap 5 hari dilakukan pengecekan kadar glukosa darah.

\section{HASIL DAN PEMBAHASAN Hasil penelitian}

Penelitian ini menunjukkan bahwa pemberian ekstrak air Ulva lactuca dapat mempengaruhi berat badan tikus DM. Data hasil pengukuran ditampilkan pada tabel di bawah ini:

\begin{tabular}{|c|c|c|c|c|c|}
\hline \multirow{3}{*}{ Perlakuan } & \multicolumn{5}{|c|}{ Rerata Berat Badan Tikus } \\
\hline & \multicolumn{5}{|c|}{$\begin{array}{c}\text { Hari ke- } \\
\end{array}$} \\
\hline & $\mathbf{0}$ & 7 & 14 & 21 & 28 \\
\hline $\mathrm{KN}$ & $201,33 \pm 1.155^{\mathrm{a}}$ & $203,67 \pm 1.528^{\mathrm{a}}$ & $209 \pm 1,000^{b}$ & $211 \pm 1,000^{\mathrm{c}}$ & $219 \pm 1,000^{\mathrm{c}}$ \\
\hline $\mathrm{Ka}$ & $203,33 \pm 2.887^{\mathrm{a}}$ & $180,67 \pm 1.528^{c}$ & $170,67 \pm 1,155^{\mathrm{d}}$ & $167,6 \pm 1,528 \mathrm{~d}$ & $160,00 \pm 1,528^{d}$ \\
\hline $\mathrm{P} 1$ & $203,67 \pm .3 .055^{\mathrm{a}}$ & $188,00 \pm 2.646^{\mathrm{b}}$ & $206,67 \pm 1,155^{b}$ & $210,00 \pm 1,00^{\mathrm{c}}$ & $219,67 \pm 1,528^{c}$ \\
\hline $\mathrm{P} 2$ & $204,67 \pm 2.517^{\mathrm{a}}$ & $177,67 \pm 1.528^{\mathrm{c}}$ & $213,33 \pm 1,528^{\mathrm{a}}$ & $224,33 \pm 2,082^{\mathrm{a}}$ & $242,67 \pm 1,528^{\mathrm{a}}$ \\
\hline P3 & $203,33 \pm 1.528^{\mathrm{a}}$ & $169,33 \pm 1,155^{\mathrm{d}}$ & $174,67 \pm 2,517^{\mathrm{c}}$ & $214,33 \pm 1,528^{b}$ & $231,67 \pm 1,528^{\mathrm{b}}$ \\
\hline
\end{tabular}

Keterangan: $\mathrm{KN}=$ Kontrol Normal, $\mathrm{K}=$ Kontrol STZ, P1 $=$ dosis $200 \mathrm{mg} / \mathrm{KgBB}, \mathrm{P} 2=\operatorname{dosis}$ $300 \mathrm{mg} / \mathrm{KgBB}$ dan $\mathrm{P} 3=$ dosis $400 \mathrm{mg} / \mathrm{KgBB}$. Angka-angka pada baris yang sama yang diikuti oleh huruf superscript yang sama tidak berbeda nyata pada taraf uji $5 \%$.

Tabel di atas menunjukkan bahwa berat badan tikus dari hari ke 0 sampai hari ke 28 mengalami perubahan, yaitu penurunan dan kenaikan yang signifikan. Pada hari ke 0, berat badan tikus hampir seragam. Hari ke-7 mulai terjadi perubahan berat badan pada masing-masing perlakuan. Penurunan berat badan terjadi pada kelompok Ka, P1, P2 dan P3 karena tikus sudah dalam keadaan DM, sedangkan pada kelompok KN cenderung naik dan berbeda nyata dibandingkan kelompok perlakuan yang lain. Berat badan pada kelompok KN cenderung naik karena tidak mengalami permasalahan pada sistem metabolisme tubuhnya. Penurunan berat badan pada kelompok Ka, P1, P2 dan P3 disebabkan oleh sistem metabolisme sel tubuh mulai terganggu yang mengakibatkan peningkatan kadar glukosa. Hal tersebut berefek pada penurunan berat badan. Gangguan metabolisme terjadi akibat kerusakan sel $\beta$ pankreas dan memicu peningkatan stres oksidatif. Radikal bebas menginduksi modifikasi struktural dan mengganggu proses glikasi pada molekul kunci saat penyerapan insulin pada sel (Reka, 2017).

Pemberian ekstak dimulai pada hari ke-7 sampai hari ke-28. Perubahan berat badan pada tiap kelompok perlakuan pada setiap pengukuran. Kelompok KN, P1, P2 dan P3 mengalami peningkatan berat badan sedangkan pada kelompok Ka terus menurun, hal ini karena kelompok Ka tetap dikondisikan diabetes dan tidak diberi perlakuan ekstrak. Berat badan pada kelompok KN naik tiap minggunya namun perubahannya lebih stabil. Data penurunan dan kenaikan berat badan tikus sebelum 
dan sesudah pemberian ekstrak diperjelas

tabel di bawah ini:

melalui persentase yang disajikan pada

Tabel 2. Persentase Penurunan Berat Badan (BB) Tikus

Setelah Dalam Kondisi DM

\begin{tabular}{|c|c|}
\hline Perlakuan & $\begin{array}{c}\text { Presentase Penurunan Rerata BB Tikus } \\
\text { Diabetes (\%) }\end{array}$ \\
\cline { 2 - 2 } & Hari Ke-7 \\
\hline KN & $-1,16$ \\
Ka & 11,14 \\
P1 & 7,69 \\
P2 & 13,19 \\
P3 & 16,72 \\
\hline
\end{tabular}

Pengukuran berat badan hari ke-7 dilakukan setelah Ka, P1, P2 dan P3 sudah dalam kondisi DM. Penurunan berat badan tertinggi adalah pada kelompok P3 yaitu $16,72 \%$ dan terendah terdapat pada kelompok P1, sedangkan kelompok $\mathrm{KN}$ tidak mengalami penurunan berat badan karena tidak dikondisikan DM. Perbedaan penurunan persentase berat badan tikus DM diakibatkan oleh metabolisme masingmasing tikus berbeda-beda dalam merespon faktor penyebab DM. Tikus ada yang mengalami DM ringan ada yang berat. Kondisi DM ringan berkaitan dengan kestabilan kondisi genetik dan internal tikus, sel $\beta$ pankreas dirusak secara lambat oleh reseptor. Kondisi DM berat diakibatkan oleh peran STZ ang menyumbangkan NO (Nitric oxide) yang mengakibatkan meningkatnya aktifitas pelepasan radikal bebas pada proses metabolisme sel, selain itu aktivasi poli ADP-ribosilasi akibat kerusakan DNA dapat menekan $\mathrm{NAD}^{+}$seluler sehingga terjadi penurunan jumlah ATP, hal ini akan menghambat sekrsi dan sintesis insulin (Saputra, 2018)

Tabel 3. Persentase Kenaikan Berat Badan (BB) Tikus Setelah Pemberian Ekstrak Air Selada Laut (Ulva lactuca)

\begin{tabular}{|c|c|c|c|}
\hline \multirow{2}{*}{ Perlakuan } & \multicolumn{3}{|c|}{ Persentase Kenaikan Rerata BB Tikus Diabetes (\%) } \\
\cline { 2 - 4 } & \multicolumn{3}{|c|}{ Hari ke- } \\
\cline { 2 - 4 } & $\mathbf{1 4}$ & $\mathbf{2 1}$ & $\mathbf{2 8}$ \\
\hline KN & 2,62 & 0,96 & 3,79 \\
Ka & $-5,53$ & $-1,76$ & $-4,57$ \\
P1 & 9,93 & 1,61 & 4,60 \\
P2 & 20,07 & 5,16 & 8,18 \\
P3 & 3,15 & 22,71 & 8,09 \\
\hline
\end{tabular}

Pengujian ekstak air Ulva lactuca berpengaruh terhadap perubahan berat badan tikus DM seperti yang ditampilkan pada tabel di atas. Jika dilihat pada masingmasing perlakuan (KN, P1, P2 dan P3) hasil pengukuran berat badan hari ke-14, ke-21 dan ke-28 mengalami peningkatan meski dengan persentase yang terkadang tinggi terkadang rendah. Pada hari ke-14, perlakuan $\mathrm{KN}, \mathrm{P} 1, \mathrm{P} 2$ dan P3 mengalami kenaikan berat badan. Peningkatan persentase paling tinggi terdapat pada kelompok perlakuan P2 (20,07\%), persentase tesebut jauh beda dibandingkan pada kelompok P1 (9,93\%) dan P3(3,15\%). Hari ke-21 peningkatan persentase berat badan tertinggi beralih pada perlakuan P3(22,71\%), persentase tersebut berbeda jauh dibandingkan pada kelompok perlakuan P1 $(1,61 \%)$ dan P2 $(5,16 \%)$. 
Kenaikan berat badan pada P1 cenderung lambat dibandingkan kelompok P2 dan P3. Hari ke-28, persentase berat badan antara P1, P2 dan P3 tetap naik, namun selisih antara P2 (8,18\%) dan P3 (8,09\%) tidak terlalu jauh dibandingkan hari sebelumnya. P1 tetap mengalami persentase berat badan namun lebih sedikit. Kelompok perlakuan $\mathrm{KN}$ dari hari ke hari tetap naik meskipun tidak tinggi dibanding kelompok P1,P2 dan P3.

Kelompok $\mathrm{Ka}$ mengalami penurunan berat badan semenjak hari ke 14 sampai hari ke 28. Hal ini disebakan kelompok $\mathrm{Ka}$ selalu dikondisikan DM. Situasi ini menyerupai penelitian yang dilakukan oleh Theresia (2017), dimana kelompok normal mengalami peningkatan berat bedan namun pada kelompok negatif terjadi penurunan berat badan yang disebabkan oleh peningkatan glikolisasi. Eksresi glukosa mengaktivasi sel $\beta$ pankreas dan meningkatkan aktivitas glukagon, dan pada akhirnya lemak yang tersimpan di tubuh akan diolah sebagai sumber energi. Akibat peristiwa tersebut, tubuh menjadi semakin kurus (Nugroho, 2012).

Data di atas menunjukkan bahwa pemberian ekstrak air Ulva lactuca berpengaruh terhadap pengembalian berat badan tikus DM. Semua kelompok tikus yang diberi perlakuan ekstrak (P1, P2 dan P3) mengalami kenaikan berat badan dari hari ke-14 hingga hari ke-28 dibandingkan kelompok $\mathrm{Ka}$, meskipun persentase peningkatan tersebut berubah ubah dan berbeda pada masing-masing kelompok. Pengaruh ini disebabkan karena ekstrak air Ulva lactuca mengandung senyawa aktif antioksidan yang berperan penting memperbaiki sistem metabolisme tubuh sehingga berat badan tikus kembali naik. Kelompok Perlakuan KN dijadikan sebagai acuan peningkatan BB pada kelompok lainnya. Jika dilihat dari angka persentase yang disajikan pada tabel 3 , peningkatan berat badan P1 lebih mendekati $\mathrm{KN}$ dibandingkan P2 dan P3. Ini membuktikan bahwa dosis terendah $(200 \mathrm{mg} / \mathrm{KgBB})$ pada
P1 dapat memperbaiki kerusakan metabolisme sel. Perlakuan P2 dan P3 memperlihatkan persentase kenaikan berat badan lebih tinggi dibandingkan $\mathrm{KN}$, kemungkinan ini karena dosis yang diberikan lebih tinggi dibandingkan P1 sehingga mempercepat pemulihan sel $\beta$ pankreas dan segera mengatasi kelainan proses metabolisme sekresi insulin. Persentase kenaikan berat badan pada hari terakhir (hari ke-28), kelompok P2 lebih tinggi dibandingkan P3 meski tidak jauh berbeda. Secara keseluruhan, persentase peningkatan berat badan pada $\mathrm{P} 1, \mathrm{P} 2$ dan P3 melebihi $\mathrm{KN}$, selain diakibatkan oleh proses perbaikan sel $\beta$ pankreas juga diakibatkan oleh kondisi tikus DM yang menyebabkan metabolisme tubuh cenderung tidak stabil. Respon tubuh masing-masing tikus berbeda, menyebabkan perbedaan angka persentase masing-masing kelompok. Eluihike (2018) menyebutkan pada hasil penelitianya, terjadi peningkatan signifikan berat badan pada hewan yang diberi ekstrak yang mengandung antioksidan (tanin) dibandingkan kelompok kontrol. Hal ini diakibatkan karena tikus mengalami kehilangan lemak dari jaringan adiposa dan katabolisme asam amino dalam jaringan otot. Terdegredasinya protein struktural menyebabkan tikus merasa cepat lapar dan asupan makanan meningkat.

Ulva lactuca mengandung berbagai senyawa fitokimia yang berpengaruh terhadap penurunan kadar glukosa darah. Beberapa penelitian menyebutkan bahwa Ulva lactuca mengandung alkaloid, flavanoid, polifenolat, monoterpen dan seskuiterpen melalui proses ekstraksi bertingkat dengan pelarut n-heksan, etil asetat dan etanol (Febriansyah, 2015). Ektsraksi Ulva lactuca menggunakan pelarut etanol mengandung alkaloid, steroid dan tanin Hasil skrining fitokimia menunjukkan ekstrak air Ulva lactuca mengandung senyawa steroid, saponin, fenol/tanin (Zulfadhli, 2018). Skrining fitokimia yang peneliti lakukan pada Ulva 
lactuca menggunakan pelarut air mengandung steroid, saponin dan tanin.

Pemberian ekstrak Ulva lactuca pada tikus diabetes berdampak pada penghambatan in vivo enzim pencernaan dan penyerapan lipid. Enzim yang disekresikan oleh pankreas akan diangkut ke usus halus dan menghidrolisis trigliserid yang tidak dapat diserap menjadi gliserol sederhana yang dapat diserap oleh usus halus. Peningkatan homeostasis glukosa darah dan lipid dapat menunda pencernaan karbohidrat dan penyerapan lipid. enzim $\alpha$ amilase dalam usus halus dan plasma yang beperan pada pemecahan pati menjadi oligosakarida (Belhadj, 2013). Senyawa polyfenol pada ekstrak mengikat sisi aktif enzim diabetes dan mengubah aktivitas katalitiknya (Osmaol et al. 2019). Kandungan saponin berperan untuk mengurangi peningkatan glukosa darah dengan cara menghambat enzim yang memecah disakarida menjadi monosakarida, mendorong penyimpanan glikogen oleh hati dan sekresi insulin oleh pulau langerhans, selain itu saponin juga berperan mengurangi glukogenesis hati, meningkatkan sintesis glikogen hati dan meningkatkan glukosa perifer dalam eritrosit dan adiposit ( El Barky, 2017). Tanin berperan sebagai antidiabetes karena memiliki kemampuan menunda penyerapan glukosa usus dan menunda timbulnya insulin dependent (Sieniawska, 2015). Tanin juga berperan menangkal radikal bebas dengan cara meningkatkan kemampuan penyerapan glukosa melalui mediator jalur persinyalan insulin seperti P38 MAPK (Mitogen-Activated Protein Kinase) dan PI3K (Phosphoinositide 3kinase) aktivasi dan translokasi GLUT-4. Tanin juga berperan untuk menghambat kinerja gen penting pada proses adipogenesis (Aba et al. 2018).

\section{KESIMPULAN DAN SARAN}

Ekstrak air selada laut (Ulva lactuca) dapat meningkatkan berat badan pada tikus DM dengan dosis 200 $\mathrm{mg} / \mathrm{KgBB}, \quad 300 \mathrm{mg} / \mathrm{KgBB}$ dan 400 $\mathrm{mg} / \mathrm{KgBB}$. Persentase peningkatan berat badan paling tinggi adalah pada dosis 300 $\mathrm{mg} / \mathrm{KgBB}$ dan $400 \mathrm{mg} / \mathrm{KgBB}$. Saran untuk penelitian selanjutnya adalah menggunakan dosis yang bervariasi dengan range yang lebih tinggi. Perlu ditambahkan perlakuan pemberian ektsrak pada kelompok tikus normal untuk melihat apakah ada pengaruh terhadap berat badan tikus.

\section{UCAPAN TERIMA KASIH}

Riset penulis dibiayai oleh Hibah Penelitian Dosen Pemula dari DRP2M DIKTI tahun 2018/2019

\section{DAFTAR PUSTAKA}

Aba, P.E and Asuzu, U. 2018. Mechanism Of Action Of Some Bioactiv Antidiabetic Principles From Phytochemicals Of Medicinal Plants: A Riview. Indian Journal Natural Products And Resources. Vol 9(2):85-96

Arbi, B. Ma'ruf, W.F. dan Romadhon. 2016. Aktivitas Senyawa Bioakti Selada Laut (Ulva lactucal) Sebagai Antioksidan Pada Minyak Ikan. Indonesian Jounal Of fisheries Science and Technology (IJFST. Vol 12(1):12-18

Belhadj, S. Hentanti, O., Elfeki, A and Hamden, K. 2013. Inhibitory Activities of Ulva Lactuca Polysaccharides On Digestive Enzymes Related to Diabetes and Obesity. Ach Physiol Biochem. 119(2):81-87.

Dinas Kesehatan Aceh. 2018. Profil Kesehatan Aceh. https://dinkes.acehprov.go.id/uploa ds/profil 2018 dinkes aceh.pdf

Hamzah, D F. 2019. Analisis Penggunaan Obat Herbal Pasien Diabetes Mellitus Tipe di Kota Langsa. Jurnal Jumantik. Vol 4(2): 168177.

Mark, D. B. 2000. Biokimia Kedokteran Dasar: Sebuah Pendekatan Klinis. Jakarta: EGC. 
El Barky, A.R., Husein, S.A., Eldeen, A.E., Hafez, Y.A. and Mohammed, T. 2017. Saponin and Their Potential Role In Dibetes Mellitus. Diabetes Manag 7(1):148-158.

Eluehike, $\mathrm{N}$ and Onoagbe. 2018. Changes In Organ And Body Weight, Serum Amylase and Antidiabetic Effect Of Tannins From Spondias Mombin On StreptozotocinInduced Diabetic Rats. Jounal Of Insulin Resistance.

Fairuz, Y. 2014. Efek Antihiperkolesteolemia dari Ampas Eksak Etanol Ganggang Hijau (Ulva lactuca L.) Pada Tikus Diabetes yang diinduksi aloksan. Skripsi. Universitas Ahhmad Dahlan. Yogyakarta.

Febriansah E.M., Sakti, E.R.E dan Kodir, R.A. 2015. Uji Aktivitas Antioksidan Ekstrak Selada Laut (Ulva lactuca) Dengan Ekstraksi Bertingkat Menggunakan Dpph. Prosiding Penelitian SPeSIA Unisba. ISSN2460-6472.

Infodantin. 2014. Pusat Data Dan Informasi Kementrian Kesehehatan RI. Jakarta.

https://www.kemkes.go.id/downloa d.php?file=download/pusdatin/info datin/infodatin-diabetes.pdf.

Infodantin. 2018. Pusat Data Dan Informasi Kementrian Kesehehatan RI. Jakarta.

Marewa, L. 2015. Kencing Manis (Diabetes Melitus) di Sulawesi Selatan. Jakata: Yayasan Obor.

Nugroho, S. 2012. Pencegahan dan Pengendalian Diabetes Melitus Melalui Olahraga. Medikora. Vol 9(1).

Orami parenting. 2019. Ternyata Ini Penyebab Berat Badan Penderita Diabetes Turun Drastis. https://Parenting.Orami.Co.Id/Mag azine/Ternyata-Ini-PenyebabBerat-Badan-Penderita-DiabetesTurun-Drastis/. Diakses tanggal 24 April 2020.
Osmaol, G.A., Gheda, S.F. Abd-Shady, A.M and Abdel-Karom, D.H. 2019. In Vitro Potential Activit O Some Weaweds As Antioxidants And Inhibitors of Diabetic Enzymes. Food Sci.Technol. DOI: httpsI://doi.org/10.1590/fst.15619.

Putra J S., Achmad A., Rahma H. 2017. Kejadian efek samping potensial terapi obat antidiabetes pasien diabetes melitus berdasarkan alogaritma naranjo. Pharmaceuticcal Journal Of Indonesia. 2(2):45:50.

Reka, P., Banu.A.T and Sethalakshmi, M. 2017. Alpha Amylase And Alpha Glukosidase Inhibition Activity Of Selected Edible Seawed From South Coast Aea Of India. Int $J$ Pharm Pharm Sci Vol 9(6): 64-68.

Rias, Y.A \& Sutikno E. 2017. Hubungan Antara BB Dengan Kadar Glukosa Darah Pada Tikus DM. Jurnal Wiyata. vol 4(1).

Rachmawani, N. R dan Oktalina, R.Z. 2017. Khasiat Pembeian Buncis (Phaseolus vulgais L) sebagai alternatif diabetes mellitus tipe 2 . Majority. Vol 6(1):71-76.

Saputra, N T., Suartha., dan Dharmayudha, A.A., 2018. Agen Diabetgonis Streptozotocin Untuk membuat tikus Putih Jantan Diabetes Mellitus. Buletin Veteriner Udayana. Vol 10(2):116-121.

Sieniawska, E. 2015. Activities Of Tannins - From In Vitro Studies To Clinical Trials. NPC. Vol 10 (11):1877-1884.

Theresia, R., Falah, S dan Safitrhi. 2017. Aktivitas Hiperglikemia Ekstrak Kulit Daun Surian (Toona sinensis) Pada Tikus Diabtes (sparaque-dawley) Yang Diinduksi Streptozotocin. Jurnal Gizi Pangan 12(3):187-194.

World Healt Organitation (WHO). 2020. https://www.who.int/newsroom/fact-sheets/detail/diabetes. diakses tanggal 25 april 2020. 
Zakaria, F.R, Priosoeryanto B P., Eniati, dan Sajida. 2017. Karakteristik Nori Dari Campuran Rumput Laut Ulva lactuca dan Euchheuma cottonii. $J P B$ Kelautan dan Perikanan. Vol 222(1):23-30.

Zhang, Y., Pan, X., Xia L., Chen J., Cao A., Wang J., Li H., Yang, K., Guo k. And Pan A. 2020. Combined lifestle factos and risk of incident type 2 diabetes and prognos among individuals with type 2 diabetes: a systematic review and metaanalysis of prospective cohort studies. Springer. Diabetologia 63:21-33.
Zulfadhli dan Rinawati. 2018. Potensi Selada Laut (Ulva lactuca) sebagai antifungi dalam Pengendalian Infeksi Saprolegnia dan Achyla pada budidaya ikan kerling (Tor sp). Jurnal perikanan topis. Vol 5(2):183-185. 